\title{
Hormone Resistance
}

National Cancer Institute

\section{Source}

National Cancer Institute. Hormone Resistance. NCI Thesaurus. Code C147564.

A finding indicating decreased tissue sensitivity to a hormone. 